\title{
Whither Homosexual Rights?
}

\author{
Tengku Ahmad Hazri*
}

The question of homosexual rights presents a formidable dilemma for contemporary Islam. And this is especially so as the Islamic world generally accepts human rights as valid aspirations, so much so that a number of scholars do not hesitate to include these as one of the higher objectives of the $\operatorname{sharl}^{c} a h$ (maqūsid al-sharī $\left.a h\right) .{ }^{1}$ This is why when calls for homosexual rights or gay rights as valid human rights are made, they attract mixed reactions.

The pressure is now increasingly felt as lobby groups and human rights organisations become more vocal. In early December 2011, US President Barack Obama and Secretary of State Hillary Clinton asserted their unflinching support for gay rights, pressuring the United Nations Human Rights Council to recognise them as human rights. According to the New York Times, the United States "would use all the tools of American diplomacy, including the enticement of foreign aid, to promote gay rights around the world."2 This emphatic declaration undoubtedly gives powerful support for this movement.

Realising the power of such pressure, a considerable segment of the Muslim constituency has offered what is perceived to be a middle way between the two extremes of endorsing homosexuality as a way to be charitable and kind to gays and yet another extreme of denying the humanity and dignity of this group. The charted middle course as taken by such scholars as Tariq Ramadan is to reject this practice while nevertheless affirming the dignity and rights of homosexuals as individuals. ${ }^{3}$ This means that while what they do is disagreeable and indeed objectionable, that alone does not justify excommunication or stigmatisation, for the values of mercy, compassion and justice dictate that such individuals should nevertheless be humanely treated. The concern in itself is valid but we submit that the reasoning of this presumed moderation is fallacious for a number of reasons, though the alternative lies in neither of the two extremes.

\section{From what One Does to what One Is}

We must remember that dignity and rights can be accorded only to human beings and it is in this sense that all attempts to recognise homosexual rights as human rights collapse. The reason is that there is no such thing as a homosexual to begin with. What is condemned by the religions of the world including Islam is an act, not a class

* Tengku Ahmad Hazri is a Researcher at IAIS Malaysia. He would like to acknowledge and thank Professors Mohammad Hashim Kamali, Osman Bakar, Karim Crow, Eric Winkel and Christoph Marcinkowski for their comments and feedback on the earlier draft of this viewpoint. 
of human beings. If the Qur'ān cursed the people of the Prophet Lut (may peace be upon him) (Qur'ān, 7:80-81, 26:165-166), it is because of what they did, not for who or what they were.

Homosexuality is actually a new way of thinking about the act, which dates back to the $19^{\text {th }}$ century, during which a "medical" view of sodomy emerged - a process which has been called the "medicalization of homosexuality" - claiming that the tendency is biologically latent in the person, who is thus already internally predisposed towards the act, even if he has not committed it. ${ }^{4}$ If historically legal and canonical codes merely forbade the act of sodomy, "the nineteenth-century homosexual became a personage, a past, a case history, and a childhood, in addition to being a type of life, a life form, and a morphology, with an indiscreet anatomy, and possibly a mysterious physiology. Nothing that went into his total composition is unaffected by his sexuality." ${ }^{\circ}$ Modern advocacy of homosexual rights thus traces its origin back to the new conception which renders the act inseparable from the person who commits it. It is an existential attribution rather than a transient action.

This confusion between the act and the person has the effect of personifying the former. As the philosopher Michel Foucault observes, "Homosexuality appeared as one of the forms of sexuality when it was transposed from the practice of sodomy onto a kind of interior androgyny, a hermaphrodism of the soul. The sodomite had been a temporary aberration; the homosexual was now a species. ${ }^{16}$ Homosexual and heterosexual thus refer to "persons who possess two distinct kinds of subjectivity, who are inwardly oriented in a specific direction, and who therefore belong to a separate and determinate human species." Identifying this tendency as a new species of human beings means that this new entity has its own nature, its own (pseudo) fitrah (human nature) so to speak. Thus the creation of human beings into male and female complementarity (Qur'ān 49:13) is being replaced with a new bipolarity of homosexuality and heterosexuality, when in fact the fitrah does not change (Qur'ān 30:30). If it is argued that the new bipolarity has a biological basis, we reply that the fitrah ultimately relates to the totality of the person - body, mind and spirit - not just one's physio-biological architecture, and thus biological aberrations can indeed constitute a hindrance to the realisation of one's fitrah. ${ }^{8}$ One may add that from a more religious perspective, the new conception implies a personification of sin the act was merely wrong, but when conflated with the whole person, he is himself the sin.

\section{The Way of Fitrah and Insān}

Such an attribution is an attempt to superimpose upon human nature an artificial concept, the homosexual, which has the tendency to distort our understanding of fitrah. Lest it be forgotten, right is haqq, which means that it has to conform to 
the true nature of things. If the freedom of human beings is asserted, then it must necessarily be a choice towards what is good, for freedom (ikhtiyār) is only a choice towards good (khayr); a choice towards what is wrong is not freedom but injustice $(z u l m) .{ }^{9}$ When we speak of the human being we mean by it the insān, whose nature (fitrah) is known fundamentally through Divine revelation, for man is not only the physical exterior but also and primarily spiritual.

It is in the spiritual essence of the human being that we find the origin of the oneness of the human family, for mankind has been created from a single soul (nafs wāhidah) (Qur'ān 4:1, 7:189). The oneness of our humanity founded on such a transcendent principle is pivotal towards the promotion of a society that is inclusive and universal because this principle is not subject to compromise and change in accordance with man's physical and biological changes. Indeed, the dignity of the human being is likewise affirmed precisely because of a similar spiritual and transcendent principle, i.e. that God has dignified mankind as declared in the Holy Qur'ān, "We (God) have dignified the sons (children) of Adam" (17:70). That plurality should emerge from the primordial unity born of a single soul has to do with the divine project so that mankind comes to know one another, one of which is the coming together of the male and the female: "O mankind! We created you from a single (pair) of a male and a female, and made you into nations and tribes, that ye may know each other" (49:13).

\section{Conclusion and Recommendations}

A conception of the human being that is rooted only in man's biological exterior without regard to his spiritual essence is susceptible to constant revision and reconsideration when new demands are made. The net result of such a conception is the creation of ever new sub-categories for the human species, each with its own distinctive fitrah as contrasted from other human beings. When the new class of human beings is established, the special rights of this group are then demanded, which in effect further removes us from our shared humanity, to say nothing of the deleterious effects this has on empathy, sympathy and genuine understanding of one another.

- The issues that are often brought up as justification for homosexual rights, such as discrimination, abuse, prejudice and so on, should not have been an issue to start with, nor should the issue be treated as if it were something new. For throughout their entire history, Islamic societies have confronted all kinds of prejudices and discriminations by upholding values that are conducive to the respect of human dignity and oneness of the human family. 
- But the way to uphold the said values is by cultivating personal relationships and nurturing our sense of compassion and mercy through deeds of care and concern, not by constructing an artificial personality and concept, whose 'rights' are then argued for.

- The undue prejudice or stigmatisation of any person for whatever misdeed he has committed is more efficiently countered with an emphatic assertion of our common humanity, that is to say, that we are human beings, or insān firmly bound to our primordial nature (fitrah).

- It is by remaining truer and firmer to our insānī essence and core that we are able to create an inclusive, empathic and caring society.

\section{Notes}

1. For example, see Jasser Auda, Maqāșid al-Sharīiah as Philosophy of Islamic Law: A Systems Approach (Kuala Lumpur: Islamic Book Trust and the International Institute of Islamic Thought, 2010), 23.

2. Steven Lee Myers and Helene Cooper, "U.S. to Aid Gay Rights Abroad, Obama and Clinton Say," New York Times, 6 December 2011, available online at http://www.nytimes.com/2011/12/07/world/ united-states-to-use-aid-to-promote-gay-rights-abroad.html?pagewanted=all (accessed on 28 February 2012).

3. Tariq Ramadan, "Islam and Homosexuality," available online at http://www.tariqramadan.com/ Islam-and-Homosexuality, 10683.html?lang=fr (accessed on 28 February 2012).

4. David F. Greenberg, The Construction of Homosexuality (Chicago: The University of Chicago Press, 1988), Chapter 9, "The Medicalization of Homosexuality”, 397-433.

5. Michel Foucault, The History of Sexuality (New York: Vintage, 1990), 1:43.

6. Ibid.

7. David M. Halperin, One Hundred Years of Homosexuality: And other Essays on Greek Love (London and New York: Routledge, 1989), 43 (emphasis original).

8. This point is made by many scholars, e.g. Shah Wali Allah, The Conclusive Argument from God (Leiden: Brill, 1995).

9. Syed Muhammad Naquib al-Attas, Prolegomena to the Metaphysics of Islam: An Exposition of the Fundamental Elements of the Worldview of Islam (Kuala Lumpur: International Institute of Islamic Thought and Civilization (ISTAC), 2001), 33. 